Brodsky, S.L. \& Neal, T.M.S. (2013). Preparing and giving expert testimony. In Koocher, G.P., Norcross, J.C. \& Greene, B.A. (Eds.) Psychologist's Desk Reference: Third Edition (604-608). New York: Oxford University Press.

Brodsky, S.L. \& Neal, T.M.S. (2013). Preparing and giving expert testimony. In Koocher, G.P., Norcross, J.C. \& Greene, B.A. (Eds.) Psychologist's Desk Reference: Third Edition (604-608). New York: Oxford University Press.

This is a pre-print version of the paper that is available as one chapter in the book referenced above. A link to the book is here:

http://global.oup.com/academic/product/psychologists-desk-reference9780199845491;jsessionid=78A0C3419166073A4F10594EF9647360?cc=us\&lang=en\&

This copy may not exactly replicate the final version published in the book. It is not the copy of record. (C) 2013 Oxford University Press 


\title{
PREPARING AND GIVING EXPERT TESTIMONY
}

\author{
Stanley L. Brodsky and Tess M.S. Neal
}

\begin{abstract}
The essential tasks for an expert witness are to be prepared, to be effective and credible on the stand, and to manage well the demands of cross-examinations. Most novice experts are excessively anxious about their testimony. Effective experts are well-oriented to the legal and scientific context of court testimony.
\end{abstract}

Key words: testimony, court, witness, forensic, expert

Facts about testifying. Effective witnesses are familiar with expected trial procedures and the dynamics of testifying. Witnesses with little or no experience need preparation before testifying (see Table 1). Inexperienced expert witnesses may not know that a) most times experts do not testify, 2) most testimony is routine, 3) clothing choice and appearance beyond a conventional threshold is largely irrelevant, 4) the best preparation does not take place immediately before the trial, and 5) it is not about winning (Brodsky, 2004).

a) Although experts are often filled with anticipatory anxiety, most cases never reach the trial stage. Most civil cases settle and most criminal cases are plea bargained before trial.

b) Most testifying experiences of expert witnesses are unremarkable, without harsh crossexaminations or vigorous attacks on the expert.

c) The appearance and clothing of lucid and persuasive experts fades into the background and has a modest impact on perceivers' evaluations of the expert. We recommend that experts dress professionally but comfortably and naturally.

d) Ongoing study and learning is the best method to prepare for testifying. Cramming just before the trial is not an effective way to prepare.

e) Being concerned about "winning" is problematic, because expert witnesses are hired to provide an objective opinion. Testimony should be the same regardless of retaining party. The psychological facts of a case are independent of referral source.

Prepare responsibly. Before testifying, ensure that your knowledge is current in psychological conceptualizations, assessment practices, and relevant professional issues. Preparation and realistic knowledge are the natural allies of good testimony. 
Familiarize yourself with the courtroom environment. New or relatively inexperienced expert witnesses anxious about testifying can work to reduce anxiety before taking the stand. Become familiar with the physical space of the courtroom in which you will testify - sit in the empty courtroom alone, observe witnesses in other trials, or ask the judge hearing the case for a waiver of the rule that excludes a witness from observing earlier testimony. Feeling comfortable in the setting will improve performance (Brodsky, 1991; 2004).

Depositions. Besides the stated purpose of discovery by opposing counsel of facts and findings, depositions serve two additional and sometimes nonobvious purposes. They inform both sides so that evidence may be weighed that would influence settlement discussions. Depositions also allow witnesses to learn the lines of inquiry that may be pursued in the trial. The following is a piece of specific advice for testifying in depositions: If you don’t know, don’t discuss. Much more than in live trials, witnesses in depositions sometimes babble on and speculate well beyond their knowledge, competence, and findings.

Understand the legal context. The legal rules of evidence and procedure profoundly affect acceptability of testimony (Committee on Ethical Guidelines for Forensic Psychologists, 1991; Specialty Guidelines for Forensic Psychology, 2011). Read one of the psychology and law texts on this subject. We recommend the book by Melton, Petrila, Poythress, and Slobogin (2007). An important issue in forensic work is whether psychological experts should answer the ultimate legal question the court has under consideration (e.g., is the defendant competent to stand trial, was the defendant sane at the time of the offense). Although there is some debate in the field, most forensic psychological scholars as well as the Specialty Guidelines for Forensic Psychology (2011) conclude expert opinions that offer ultimate conclusions, especially about mental state at time of offense, are not proper. This conclusion rests on the fact that psychological observations, inferences, and conclusions are distinct from legal facts, opinions, and conclusions. We recommend experts become familiar with "the ultimate issue issue" (see Melton et al., 2007) and further, that experts do not testify to the ultimate legal issue, except in cases of involuntary commitments and certain other situations. Instead, we suggest testifying about findings and conclusions based soundly in psychological science, and allow the trier-offact to extrapolate how those psychological findings apply to the ultimate legal issue at question.

Testify only within the scope of reasonable and accepted scientific knowledge. Experts are bound to this standard by the U.S. Supreme Court Daubert decision. Research results should 
be used in an impartial manner in the face of adversarial pulls of attorneys. It is not unethical to disagree with other experts about readings or applications of knowledge. It is unethical to relinquish the role of neutral expert in favor of highly selective gleaning of knowledge (Sales \& Shuman, 2005).

Stay clearly within the boundaries of your own professional expertise. This mandate from the APA Code of Ethics (Knapp, 2011) means that practitioners with expertise only in psychology of adults do not assess children or testify about child psychology and vice-versa. In the same sense, one should not consider observation of other witnesses' behavior on the stand to be remotely equivalent to findings from conventional psychological assessments.

Credentials. Skilled opposing counsel can always find something you have not accomplished, written, or mastered. Admit all nonaccomplishments in a matter-of-fact way. It is okay.

Experience. The legal system uses breadth, depth, and duration of experience as part of credentialing expert witnesses. Clinicians should be aware that, by itself, clinical experience is at best modestly related to accuracy of diagnostic judgments. Early studies and reviews indicated no relation between clinical skills and experience (e.g., 1994; Garb, 1989), while a more recent meta-analysis indicated about a 13\% improvement in diagnostic accuracy with experience (Spengler at al., 2009).

Credibility. An implicit goal of witnesses is to be credible and believed. People believe witnesses who are likable and confident. To the extent possible, given the nature of the setting, allow the likable aspects of who you are to be visible, and confidently present your findings and conclusions.

Use effective verbal language. Tell a compelling story with your testimony and present your message in a sensible and approachable way. Avoid exaggeration, unfamiliar words, dramatic and emotional words, a monotone voice, and overqualifying what you say. Instead, be calm and poised, talk slowly enough to allow your message to be processed, vary the format of your answers, and personalize your testimony by using personal pronouns (e.g., "I” and “we”). Treat the jurors as interested lay acquaintances rather than colleagues (Brodsky, 2004).

Use narrative statements when possible. Persuasive witnesses use smoothly flowing statements and make the testimony come alive by creating a meaningful story about the defendant or litigant. Narrative answers tell a compelling story, as opposed to fragmented 
answers, which are shorter and more broken and thus more difficult to follow. Good attorneys will allow for narrative answers on direct examination, and good attorneys will try to prevent narrative answers on cross-examination. Look for opportunities to provide narrative answers during both direct and cross-examination (Brodsky, 1991; 2004).

Use effective nonverbal language. Nonverbal language accounts for more of the variance in person perception than verbal language. Eye contact is one of the most important nonverbal communication tools at your disposal. It is natural to look at the person(s) with whom you are speaking - which is most often the attorney during testimony; however, looking at the jury and judge is also important during narrative answers. What is hard is avoiding being captured in eye contact solely with the cross-examining attorney. Look for opportunities to provide narrative answers, and make sure to look at the jury as you answer (Brodsky, 1991; 2004).

Admit ignorance. Some expert witnesses present themselves as omniscient and infallible in their fields. Don’t. Instead, state “I don't know” in response to queries when you truly do not know the answer.

Data that do not support your conclusions. Excessively partisan witnesses attempt to deny existing information they have gathered that contradicts their conclusions. Conscientious and responsible witnesses freely and without defensiveness acknowledge and discuss contradicting information.

Handling cross-examination attacks and bullying. One way to prepare for the possibility of a tough cross-examination experience is to understand cross-examination techniques through the eyes of the attorney. Chastisement, cornering, and bullying are techniques some attorneys use to intimidate or discredit the witness (Brodsky, 2004). Good witnesses retain control by using simple, reflective answers. Do not try to be equally aggressive or loud to match the style of the cross-examining attorney. These responses diminish credibility and the appearance of impartiality. Instead, attempt to present yourself in the opposite way; that is, if the attorney demands an immediate and unreasonable response, answer in a careful and reasoned way. If the attorney is loud and insistent, reply with quiet, measured, and assured responses (Brodsky, 2004). Maintaining professional poise and effectively handling personal attacks and bullying during cross-examination takes practice, which you can do by yourself in front of a mirror or with a colleague. Videotaping your practice and critically examining your responses is also a good way to prepare yourself for the possibility of a tough cross-examination. 
Use evaluations and testimony as stimuli to learn. Evaluators and witnesses are typically so caught up in "doing” that they are not open to conceptualizing cases and testimony as learning experiences. We suggest asking, "What additional validated measures might I administer that are directly related to these forensic issues? What else should I read or what sort courses should I take to be better prepared? What have I learned about my own needs for professional and scholarly growth?”

Table 1. The Courtroom-Oriented and the Courtroom-Unfamiliar Expert Witness

\begin{tabular}{|c|c|c|}
\hline Stage & Courtroom Oriented & Courtroom Unfamiliar \\
\hline & Pretrial & \\
\hline Training & $\begin{array}{l}\text { Forensic psychology graduate } \\
\text { programs or post-docs, legal-medical } \\
\text { institutes, or other training centers. } \\
\text { Sometimes self-taught. }\end{array}$ & No relevant training. \\
\hline $\begin{array}{l}\text { Point of entry of witness } \\
\text { into proceeding }\end{array}$ & $\begin{array}{l}\text { Early in proceedings; pretrial } \\
\text { conferences with emphasis on } \\
\text { appropriate questions to elicit } \\
\text { evaluation-related content. }\end{array}$ & $\begin{array}{l}\text { Late entry; minimal or no } \\
\text { pretrial conferences with } \\
\text { attorney; minimal preparation } \\
\text { with attorney on techniques for } \\
\text { eliciting forensic opinions. }\end{array}$ \\
\hline $\begin{array}{l}\text { Knowledge of law, } \\
\text { evidence, and, privilege }\end{array}$ & $\begin{array}{l}\text { Usually aware; occasionally more } \\
\text { aware than the lawyer in the trial. }\end{array}$ & $\begin{array}{l}\text { Sometimes aware or minimally } \\
\text { informed. }\end{array}$ \\
\hline Record keeping & $\begin{array}{l}\text { Thorough; organized to anticipate } \\
\text { cross-examination; exact as to dates, } \\
\text { times, places, detail, prior hospital } \\
\text { records. }\end{array}$ & $\begin{array}{l}\text { Often is variable, imprecise; } \\
\text { omits or uncertain of dates, } \\
\text { times. }\end{array}$ \\
\hline Reaction to subpoena & $\begin{array}{l}\text { Minimal emotional reaction; reviews } \\
\text { record, calls lawyer, determines basis } \\
\text { of subpoena and information desired. }\end{array}$ & $\begin{array}{l}\text { Distress and anxiety; no } \\
\text { conferences unless requested by } \\
\text { lawyer; unaware of legal } \\
\text { position. }\end{array}$ \\
\hline
\end{tabular}




\begin{tabular}{|c|c|c|}
\hline & On the witness stand & \\
\hline Written report & $\begin{array}{l}\text { Clear, concise, equivocal when } \\
\text { necessary; avoids legal conclusions } \\
\text { but answers questions raised. }\end{array}$ & $\begin{array}{l}\text { Technical language, poorly } \\
\text { understood by lay audiences; } \\
\text { often does not answer legal } \\
\text { questions. }\end{array}$ \\
\hline Target of testimony & Jury or judge. & $\begin{array}{l}\text { Lawyer or mental health } \\
\text { colleagues. }\end{array}$ \\
\hline Language & Spoken English. & Professional terminology. \\
\hline Purpose of testimony & Teaching; may advocate for findings. & $\begin{array}{l}\text { Non-persuasive presentation of } \\
\text { clinical information. }\end{array}$ \\
\hline Testimony process & $\begin{array}{l}\text { Steady; consistent; aware of "traps"; } \\
\text { concedes minor points easily. }\end{array}$ & $\begin{array}{l}\text { May be badly manipulated; } \\
\text { stubborn; backed into corner. }\end{array}$ \\
\hline \multirow[t]{2}{*}{$\begin{array}{l}\text { Reaction to cross- } \\
\text { examination }\end{array}$} & $\begin{array}{l}\text { Normal acceptance as routine } \\
\text { procedure. }\end{array}$ & Resentment, anger, confusion. \\
\hline & Posttrial & \\
\hline $\begin{array}{l}\text { Reaction after court } \\
\text { findings, especially to } \\
\text { distortion of opinion and } \\
\text { loss of case by retaining } \\
\text { counsel }\end{array}$ & $\begin{array}{l}\text { Acceptance; learns; reappears in } \\
\text { court. }\end{array}$ & $\begin{array}{l}\text { Nonacceptance; alienated; } \\
\text { reacts by future avoidance. }\end{array}$ \\
\hline $\begin{array}{l}\text { Results of court } \\
\text { adjudication }\end{array}$ & $\begin{array}{l}\text { More consistent with expressed view } \\
\text { of witness. }\end{array}$ & $\begin{array}{l}\text { Less consistent with expressed } \\
\text { view, particular in cases with } \\
\text { opposing testimony. }\end{array}$ \\
\hline Fees & $\begin{array}{l}\text { Higher, based on actual time spent in } \\
\text { evaluation, reporting, and courtroom } \\
\text { time. }\end{array}$ & $\begin{array}{l}\text { Variable, generally low or } \\
\text { occasionally unrealistically } \\
\text { high. }\end{array}$ \\
\hline
\end{tabular}

Note. This table has been modified substantially from the original version by Brodsky and Robey (1973) and the revision by Brodsky (1991). 


\section{For More Information}

Brodsky S. L. (1991). Testifying in court: Guidelines and maxims for the expert witness. Washington, DC: American Psychological Association.

Brodsky, S.L. (2004). Coping with cross-examination and other pathways to effective testimony. Washington, DC: American Psychological Association.

Committee on Ethical Guidelines for Forensic Psychologists. (1991). Specialty guidelines for forensic psychologists. Law and Human Behavior, 15, 655-665.

Garb, H. N. (1989). Clinical judgment, clinical training, and professional experience. Psychological Bulletin, 105, 387-396.

Knapp, S.J. (Ed). (2011). APA handbook of ethics in psychology (2 volumes). Washington, DC: American Psychological Association.

Melton, G., Petrila, J., Poythress, N. G., \& Slobogin, C. (2007). Psychological evaluation for the courts: A handbook for mental health professionals and lawyers (Third Edition). New York: Guilford Press.

Sales, B. D., \& Shuman, D. W. (2005). Experts in court: Reconciling law, science, and professional knowledge. Washington, DC: American Psychological Association.

Specialty Guidelines for Forensic Psychology. Specialty Guidelines for Forensic Psychologists, approved by the APA Council of Representatives August 3, 2011. Retrieved from: http://www.ap-ls.org/aboutpsychlaw/SpecialtyGuidelines.php January 3, 2012.

Spengler, P. M., White, M. J., Ægisdóttir, S., Maugherman, A. S., Anderson, L. A., Cook, R. S., Nichols, C. N., Lampropoulos, G. K., Walker, B. S., Cohen, G. R., \& Rush, J. D. (2009). The metaanalysis of clinical judgment project: Effects of experience on diagnostic accuracy. The counseling psychologist, 37(3), 350-399 